\title{
INSPIRING SECURITY COOPERATION: THE EU, ARF, ASEAN AND MYANMAR
}

\author{
Ludovica Marchi*
}

This article regards the European Union's endeavours at the Association of Southeast Asian Nations (ASEAN) Regional Forum (ARF) to motivate ASEAN and Myanmar to connect with multilateral security cooperation. It discusses two assumptions: The EU made efforts to inspire ASEAN to undertake responsibilities; and the EU tried to encourage Myanmar to engage in security cooperation. It employs an approach underpinned by Checkel's (1999) social theory, March and Olsen's (1998) logic and observations provided by several interviewees (Southeast Asia and Brussels). It relates to the aftermath of Cyclone Nargis that hit Myanmar in 2008 causing thousands of deaths as the context of this case study. The article investigates several questions: Has ASEAN responded to the EU's invitation to take courage in shouldering responsibility? Has Myanmar coped with the EU's call to join the multilateral security framework of cooperation? And, lastly, have any lessons been derived from Myanmar's Nargis incident with regard to the European Union's foreign and security policy?

INTRODUCTION

I. THE EU AT ARF

II. ThE CONTEXT OF THE CASE STUDY ................................................ 811

III. LESSONS LEARNT FROM ASEAN? .................................................. 812

IV. LESSONS LEARNT FROM MYANMAR? ........................................... 813

V. LESSONS LEARNT FROM THE EU? ................................................ 815

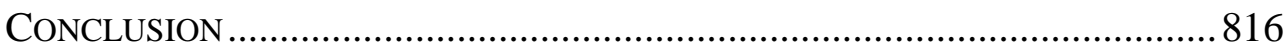

\section{INTRODUCTION}

This article focuses on the European Union's endeavours at the Association of Southeast Asian Nations (ASEAN) Regional Forum (ARF) ${ }^{1}$ to motivate ASEAN and Myanmar to connect with multilateral security

\footnotetext{
* Ludovica Marchi, Ph.D., (pen name of Ludovica Marchi Balossi Restelli) is an international relations political scientist, Visiting Fellow at the Centre for International Studies, Department of International Relations, London School of Economics and Political Science, Houghton St, London WC2A 2AE (UK). Research fields: European Union's External Relations, ASEAN, ARF, Myanmar, Common Security and Defence Policy, Italy's Foreign Policy, Foreign Policy Analysis.

${ }^{1}$ ARF is formed by the ten ASEAN members (Indonesia, Malaysia, the Philippines, Singapore, Thailand, Brunei, Vietnam, Laos, Myanmar and Cambodia) and ASEAN's dialogue partners (Australia, Canada, China, the European Union, India, Japan, South Korea, Russia, New Zealand, the United States, Papua New Guinea, Mongolia and North Korea).
} 
cooperation. It is built around two assumptions: First, the EU made efforts to inspire ASEAN to undertake responsibility; and this investigation will discuss how Checkel's ${ }^{2}$ social mechanisms justify ASEAN's crisis support for Myanmar. Second, the EU attempted to encourage Myanmar to engage in security cooperation; and the article will debate how far March and Olsen $^{3}$ explain the logic behind Myanmar's attempted cooperation. In order to discuss these assumptions, a further analytical tool is needed, which is the observations made during interviews conducted in Southeast Asia and Brussels (2013-2014). Hence, the article's method of enquiry is formed by the joint relationship between Checkel's social theory, March and Olsen's logic and the interviewees' explanations.

The context within which this case study is set is the aftermath of Cyclone Nargis that devastated Myanmar in 2008 causing several thousands deaths. The article argues that, while the EU sought to convince Myanmar to compromise and link to cooperation, the latter, overwhelmed by Nargis, albeit indirectly, encouraged the EU Council to insert the responsibility to protect (R2P) goal into the 2008 European Foreign and Security Policy. The EU has a particular interest in the ASEAN Regional Forum since it is the "leading platform in Asia for dialogue and cooperation on security", ${ }^{4}$ and it co-chairs the meetings with ASEAN, the ARF's founding member (1994). Two years after ARF was instituted, Myanmar was accepted into the Forum. The ARF's co-chaired summary reports have tended to be employed as the sources for this investigation. Summing up, this article investigates several questions: Has ASEAN responded to the EU's invitation to take courage in shouldering responsibility? Has Myanmar coped with the EU's call to join the multilateral security framework of cooperation? And, lastly, have any lessons been derived from Myanmar's Nargis incident related to the European Union's foreign and security policy?

\section{THE EU AT ARF}

At the Forum, the EU publicised the multilateral aspects of its policy in the field of security on the basis of its experience and aspiration to encourage others to follow. At the ARF Inter-Sessional Support Group on Confidence Building Measures, which it co-chaired in Potsdam (February

\footnotetext{
${ }^{2}$ Jeffrey Checkel, Social Construction and Integration, 6(4) JouRnAL OF EUROPEAN PUBLIC POLICY 545 -560 (1999).

${ }^{3}$ James March and Johan Olsen, The Institutional Dynamics of International Political Orders, ARENA WORKING PAPER 98/5 (1998).

${ }^{4}$ General Background on the AsEan Regional Forum, European Union External Action, Brussels, available at www.eeas.europa.eu〉EUROPA〉EEAS〉Asean>News.
} 
21-23, 2005), the EU, through its delegates, emphasised what was conceivably the success of the multilateral participation in approaching security situations. The EU officials explained that governments acting unilaterally were placing themselves at a disadvantage, and that multilateral arrangements more easily antagonised complex situations. ${ }^{5}$

At the other ARF Inter-Sessional Support Group on Confidence Building Measures and Preventive Diplomacy co-chaired by the European Union in Helsinki (March 28-30, 2007), the EU's multilateral influence featured in the explanation (to the ASEAN nations, Myanmar and the other ARF partners) of its joint activity with the Organisation of Security and Cooperation in Europe (OSCE). ${ }^{6}$ At the following workshop in Berlin (2008), representatives of the EU elucidated the practices associated with an "open" dialogue on security. They defended the adoption of a common security concept, together with the development of politically binding standards, and the gradual institutionalisation of cooperation, all of which they presented as processes offering a solid and durable basis for security collaboration. ${ }^{7}$ These discourses promoted at the ARF's groups and subgroups, as well as at general meetings, aimed at fostering the participants' multilateral behaviour.

\section{The ConteXt OF THE CASE STUdY}

In May 2008, Cyclone Nargis ravaged Myanmar's Irrawaddy Delta, causing widespread destruction and loss of life. Myanmar's military junta refused external help and did little to reduce the difficulties that arose in that situation. ARF did not engaged in the action. ASEAN was far more active, facilitating the constitution of the ASEAN Humanitarian Task Force, led by the ASEAN Secretary General and operated through the Tripartite Core Group (TCG: The Government of Myanmar, ASEAN and the UN), coordinating the relief work and delivering assistance. ${ }^{8}$ Two situations derived from this: ASEAN provided crisis support for Myanmar; and

\footnotetext{
${ }^{5}$ Co-Chairs' Summary Report of the meeting of the ASEAN Regional Forum Inter-Sessional Support Group on Confidence Building Measures, Berlin/Potsdam, Germany, February 21-23, 2005.

${ }^{6}$ Co-Chairs' Summary Report of the meeting of the ASEAN Regional Forum Inter-Sessional Support Group on Confidence Building Measures and Preventive Diplomacy, Helsinki, Finland, March 28-30, 2007.

${ }^{7}$ Co-Chairs' Summary Report of the ARF Workshop on Confidence Building Measures and Preventive Diplomacy in Asia and Europe, Berlin, March 12-14, 2008.

${ }^{8}$ Jurgen Haacke and Noel Morada, The ARF and Cooperative Security: More of the Same? In CoOperative Security in the Asia-Pacific: The Asean Regional Forum 219-232, 228 (Jurgen Haacke \& Noel Morada eds., Oxford: Routledge 2010); Also Andrew Selth, Even Paranoids Have Enemies: Cyclone Nargis and Myanmar's Fears of Invasion, 30(3) CONTEMPORARY SOUTHEAST ASIA $379-402(2008)$.
} 
Myanmar accepted the relief operation backed by ASEAN. Might ASEAN have followed the EU's suggestion about assuming responsibility, and might Myanmar have followed the EU's advice to join the multilateral security framework? The following two sections will attempt to answer these questions: "Lessons learnt from ASEAN?" and "Lessons learnt from Myanmar?"

\section{LESSONS LEARNT FROM ASEAN?}

How ASEAN, in the end, engaged itself in crisis support for Myanmar is explained by Checkel's social theories, which suggest that there are processes whereby actors acquire new interests and preferences through contact with other contexts, either discursive structures or norms. ${ }^{9}$ Three points deal with this explanation: Group learning, the ability to persuade and the crisis and policy failure argument.

(i) Group learning. The transformative discourses developed at the ARF meetings seek to encourage group learning and dispense norms as vehicles of new interest. ${ }^{10}$ The Inter-sessional Support Group on Confidence Building Measures, the Peacekeeping groups, and those related to Search, Rescue and Disaster Relief, received growing support from the personnel from the EU External Service (EEAS) and the Crisis Response and Operational Coordination section, ${ }^{11}$ as well as from the European Commission's Humanitarian Aid Office (ECHO). ${ }^{12}$ These personnel, when interviewed, confirmed that the frequency of the networking promoted new learning, and interactions developed new interests. This result is congruent with Checkel's belief that "where a group met repeatedly, and where there was a high density of interactions among participants", new interests are most likely to be generated. ${ }^{13}$

(ii) The ability to persuade was a further factor contributing to the development of new preferences and goals. The interviewed ASEAN leaders close to the ARF organisation ${ }^{14}$ and Southeast Asian security policy analysts ${ }^{15}$ acknowledged that those involved in the Forum's activities (in terms of training and assisting with the practical exercises, the EEAS and

\footnotetext{
${ }^{9}$ Checkel, Op. Cit., at 548.

${ }^{10}$ Ibid.

${ }^{11}$ Author's Interview with Official (B) of the EEAS, of the Crisis Response and Operational Coordination (Brussels, June 2014).

${ }^{12}$ Author's Interview with Official (C) Rapid Response Coordinator, European Commission (Brussels, June 2014).

${ }^{13}$ Checkel, Op. Cit., at 549.

${ }_{15}^{14}$ Author's Interview with ASEAN Leaders (D) close to the ARF Organisation (Canberra, Sept. 2013).

${ }^{15}$ Author's Interviews with Southeast Asian Security Policy Analysts (E) (Singapore, Feb. 2014).
} 
ECHO personnel, and those from OSCE), in most cases, had an enhanced persuasive capability, which they accredited to the authority of their position, and had the power to influence the actors' inclinations. This explanation too, obtained from the interviews, matches Checkel's suggestion that, when the persuader was an authoritative member of the group to which the persuadee belonged/wished to belong, persuasion was most likely to materialise. ${ }^{16}$

(iii) Also, the crisis and policy failure dynamics were able to develop new commitments and roles. The ASEAN leaders ${ }^{17}$ suggested that, during the crisis of the cyclone, the ASEAN group felt an added responsibility, and the role of dealing with the situation emerged as a duty. In addition, the foreign policy of Myanmar's junta to refuse the help of external donors and the lack of capability to provide assistance to its own people provided evidence of policy failure. ${ }^{18}$ The reasons proposed by the above leaders reconnect with Checkel's proposition that the development of new purposes and roles is more likely to occur "where the group felt itself in a crisis or was faced with clear evidence of policy failure". 19

In the end, it is understandable that new interests, commitments and roles easily lead actors to engage in new responsibilities. Hence, Checkel's argument, as substantiated by the interviewees, provided a justification for ASEAN embarking on the crisis support action. Yet, concerning this paper's first assumption, has ASEAN responded to the EU's encouragement at the Forum to undertake responsibility? The officers questioned, this time in Brussels (from the EEAS and ECHO) ${ }^{20}$ confirmed that their own activity within the ARF groups and sub-groups was intended to transmit new norms, that would be assimilated and lead to others' undertakings. They outlined a scenario which agreed with Checkel's notion that social dynamics created "new drives" (responsibilities, duties, obligations, tasks), which grew via contact with other contexts. ${ }^{21}$

\section{LESSONS LEARNT FROM MYANMAR?}

Myanmar's acceptance of ASEAN's (and others) disaster relief assistance indicated a change in the junta's attitude towards rejecting interference in its own affairs, which March and Olsen's theory seeks to explain. These scholars" "logic of expected consequences" suggests that the

\footnotetext{
${ }^{16}$ Checkel, Op. Cit., at 550.

${ }^{17}$ Author's Interviews with ASEAN Leaders (F) (Macau, May 2013).

${ }^{18}$ Selth 2008, Op. Cit.

${ }^{19}$ Checkel, Op. Cit., at 549.

${ }^{20}$ Author's Interviews (B) and (C), Op. Cit.

${ }^{21}$ Checkel, Op. Cit., at 548.
} 
strategic calculation of the rational bargaining of a government's protection and defence of what it perceives as its national interest confronts, but frequently, also, becomes reconciled with the position of other states regarding the same policy issue. ${ }^{22}$ In the post-Nargis situation, the strategic calculation of rational bargaining by Myanmar's junta challenged the position of the other actors, specifically ASEAN, and the ASEAN Secretariat, who were willing to network with Myanmar's government. The rational bargaining challenge was, firstly, manifested by the junta's rejection of external help, and the defence of what it perceived to be the national interest.

Only subsequently did a different logic emerge that March and Olsen explain as the "logic of appropriateness". ${ }^{23}$ To justify this change, the interviewees $^{24}$ suggested several reasons which included the moral aspect of safeguarding its citizens, understanding the value of collective regional security, strengthening regionalism in Southeast Asia and, not least, endorsing cooperation. A strong motive proposed by a Southeast Asian security analyst ${ }^{25}$ was the confidence factor that the ASEAN's assistance mission was to remain under Myanmar's junta's own control, which was key to its acceptance. This assertion merely recalls the EU's efforts, at ARF, to develop confidence-building dialogues and generate a reliance on security and humanitarian operations.

Yet, concerning this paper's second assumption, is Myanmar's acceptance of the relief operation (and, so far, their cooperation with the group) related in any way to the EU's indication to join the multilateral security framework? The answer lies in the fact that the incentives for Myanmar's change, highlighted by the interviewees, are the proposals that the EU discussed at the Forum. Without doubt, the ethical dimension of the responsibility to protect their own people, that the interviewees indicated as a duty of ASEAN, with Myanmar there within, is distinct to the EU, as is the belief in the value of collective regional security. Likewise, the trust in reinforcing regionalism in Southeast Asia is key to both the EU's idea of security and participation in the ARF. ${ }^{26}$ That Myanmar's junta should

\footnotetext{
${ }^{22}$ March and Olsen, Op. Cit., at 950.

${ }^{23}$ Ibid., at $951-952$.

${ }^{24}$ Author's Interviews with: Myanmar Historian (H) (Yangon, July 2014); Officer (I) of the ASEAN Secretariat (Macau, May 2013); Security Analyst (J) Centre for Non-Traditional Security Studies (NTS), S. Rajaratnam School of International Studies (RSIS), Nanyang Technological University (Singapore, Febr. 2013); Southeast Asian Security Policy Analysts (G) (Singapore, Feb. 2014). See Ludovica Marchi, The EU's Role in Developing Security Cooperation with Myanmar at the ASEAN Regional Forum: 2004-2008, 25(2) EUROPEAN SECURITY 197-275, 209-210 (2016).

${ }^{25}$ Author's Interview (G), Op. Cit.

${ }^{26}$ General Background on the AsEan Regional Forum, Op. Cit.
} 
engage in reforms, as advanced by the interviewees, has always been demanded by the EU, and, also, the principle of continuing cooperation among the regional partners is something that the EU predicates at all times. In the end, the motivations mentioned by the interviewees appear to be connected with the EU's encouragement of Myanmar to accept multilateral security solutions. Yet, Cyclone Nargis, that overwhelmed Myanmar, prompted other reactions which closely involved the European Union.

\section{LESSONS LEARNT FROM THE EU?}

In the aftermath of the cyclone, the EU Council assessed the Union's performance in terms of whether the EU, during the Nargis incident, acted in accordance with its identity and norms. ${ }^{27}$ In 2003, the Council ratified the rule concerning the readiness "to share in the responsibility for global security", ${ }^{28}$ and later, in 2005, it was at the forefront of the diplomacy that resulted in the UN General Assembly's agreement with the notion of a "responsibility $[\ldots]$ to help protect populations from genocide, war crimes, ethnic cleansing, and crimes against humanity". ${ }^{29}$ Despite these decisions, the EU remained "normatively unclear" on whether it was obliged "to assist in circumstances like that of Myanmar's Nargis". ${ }^{30}$ In November 2008, the Council discussed the state of affairs of its security policy arguing that, after five years of civilian missions, a "large body of information and experience [was] available which needed to be captured in a systematic lessons learned" exercise. ${ }^{31}$ A lesson has derived from the Myanmar's Nargis incident to the extent that the Council faced a process that March and Olsen describe as being motivated by the "appropriateness logic". The latter suggests that "action involves evoking an identity or role, and matching the obligations of that identity or role to a specific situation". ${ }^{32}$ Cyclonedeprived Myanmar contributed towards encouraging the sense of obligation that is embedded in the EU's identity. It moved forward the Council's new

\footnotetext{
${ }^{27}$ AdAPting the EU's Approach to Today's SeCurity Challenges 28, European Union Committee, 21 November, 31st Report of Session 2007-2008 (2008), available at www.publications.parliament.uk/pa/ld200708/ldselect/ldeucom/.../190.pdf.

${ }^{28}$ European Security Strategy: A Secure Europe in a BetTer World, European Council (Brussels, Dec. 12, 2003).

${ }^{29}$ Ludovica Marchi, Fit for What? Towards Explaining Battlegroup Inaction, 20(2) EUROPEAN SECURITY 155-184, 157 (2011).

${ }^{30}$ AdAPting THE EU's APPROACH, Op. Cit., at 28.

${ }^{31}$ Council of the European Union, General Affairs and External Relations 16 (Press Release 15394/08 (Presse 318), November 10, 2008), available at http://www.consilium.europa.eu/uedocs/cms_data/docs/pressdata/en/gena/104053.pdf.

${ }^{32}$ March and Olsen, Op. Cit., at 951.
} 
logic, which has been endorsed by law, ${ }^{33}$ and that agreed on a "Europe de la securite' humaine" as a concept that embraced "natural disasters" and "multiple sources of insecurity". ${ }^{34}$ This concept was acknowledged as appropriate in a response to the Council's question of "whether or not the humanitarian assistance to the people affected by the cyclone, in Myanmar, was a reason for the responsibility to protect". ${ }^{35}$

\section{CONCLUSION}

This article has focused on the EU's attempts, at ARF, to persuade ASEAN and Myanmar to connect with security cooperation. Concerning the assumption that the EU made efforts to inspire ASEAN to undertake responsibility, this investigation has shown that Checkel explains how social mechanisms lead to the development of new roles and by adducing the Brussels' interviewees' explanations that their duty at ARF aimed to communicate norms, hopefully guiding others to engage in action, such as the relief operation supporting Myanmar - the investigation has shown that ASEAN responded to the EU's proposal at the Forum to assume responsibility.

Concerning the other assumption by the $E U$ which tried to encourage Myanmar to engage in security cooperation, the article shed light on March and Olsen's appropriateness logic, which justified the junta's relaxation of its stance and agreement to cooperate. Moreover, by presenting the interviewees' justifications of the Yangon's changed logic, the investigation has demonstrated the link between Myanmar's new stance and the EU's efforts to convince Yangon to operate within the multilateral security framework.

In the end, by showing that the EU Council is committed both to discussing its own civilian missions' performance and to focusing on a lessons learnt effort, this article has argued that, as the EU aimed to persuade Myanmar to compromise and join the cooperation, Myanmar, hit by Nargis has, implicitly, motivated the Council to include the R2P goal within the 2008 European Foreign and Security Policy. On the whole, this investigation has shown how the combination of Checkel's social theory, March and Olsen's logic and the interviewees' justifications, in a joint relationship, contributed towards a discussion of this article's assumptions.

\footnotetext{
${ }^{33}$ REPORT ON THE IMPLEMENTATION OF THE EUROPEAN SECURITY STRATEGY—PROVIDING SECURITY IN A Changing World 12 (S407/08, Brussels, December 11, 2008), available at http://www.consilium.europa.eu/ueDocs/cms_Data/docs/pressdata/EN/reports/104630.pdf.

${ }^{34}$ AdaPting the EU's APPROACH, Op. Cit., at 39.

${ }^{35} \mathrm{Ibid}$., at 28.
} 